\title{
EFISIENSI DANA HIBAH, KREATIVITAS, PENDAMPINGAN DAN IMPLEMENTASI TEKNOLOGI TEPAT GUNA PADA NILAI EKONOMI HASIL USAHA MITRA
}

\author{
(EFFICIENCY OF GRANT FUNDS, CREATIVITY, ASSISTANCE AND \\ IMPLEMENTATION OF APPROPRIATE TECHNOLOGY ON THE \\ ECONOMIC VALUE OF THE PARTNER'S BUSINESS RESULTS)
}

\author{
Oleh: \\ Sunarso ${ }^{1)}$, Taufik ${ }^{2)}$, Irwan Kurniawan ${ }^{3)}$ \\ Sekolah Tinggi Ilmu Ekonomi IPWI Jakarta1,2,3) \\ sunarso.ipwija@yahoo.com ${ }^{1)}$, alwitaufik@yahoo.com ${ }^{2)}$,h_irwan74@yahoo.co.id ${ }^{3)}$
}

Submit: 10 Nov 2019 Review: 23 Dec 2019 Accept: 23 Dec $2019 \quad$ Publish: Dec 2019

\begin{abstract}
This paper analyzed the efficiency of grant fund, creativity, assistance and implementation of appropriate technology on the economic value of the partner's business results based on the technological dissemination at two farmer groups that have been chosen as partners of the program. The objects of this reaserch are two groups of farmers who cultivating croops, namely KUBE Sukamakmur and Saung Cipamingkis Farmers Groups in the village of Sukamulya, Bogor West Java. Data collection methods used field observations and interviews with respondents consisting of partner farmers. It consists of 20 DMUs that divided into 5 food commodity clusters from 2 partner groups. The interview aims to obtain a general picture of the food crop farming of the farmers who are partners who are the object of research. Analysis of research data based on Data Envelopment Analysis (DEA). The research result showed that in the aspect of fund efficiency which has a technical efficient value reaches $100 \%$ only in 2 DMUs, namely DMU 19 and DMU 10, which are cluster S (cassava commodities). In the aspect of creativity efficiency, it can be seen that only in DMU 19 and DMU 20 (cluster S or cassava commodity) are efficient. The level of relative efficiency in the assistance efficiency there was only $1 \mathrm{DMU}$ which is efficient, namely DMU 19 in cluster S (cassava commodity). The level of efficiency in the aspect of appropriate technology (technical efficiency), only achieved by $1 \mathrm{DMU}$, namely DMU 19 in cluster $S$ (Cassava). This also shows that as many as 19 DMU are marked inefficiencies from the acquisition of efficiency values $<100 \%$.
\end{abstract}

Keywords:

Appropriate technology, creativity, assistance, grant fund, efficiency, economic value.

\section{ABSTRAK}

Artikel ini menganalisis Efisiensi Dana Hibah, Kreativitas, Pendampingan dan Implementasi Teknologi Tepat Guna pada Nilai Ekonomi Hasil Usaha Mitra, pada dua kelompok tani yang telah dipilih sebagai mitra tani. Objek penelitian ini adalah dua kelompok petani Kelompok Usaha Bersama (KUBE) dan Kelompok Tani Saung Cipamingkis di Desa Sukamulya, Bogor, Jawa Barat. Metode 
pengumpulan data menggunakan observasi lapangan dan wawancara dengan responden yang terdiri dari petani mitra yang terdiri dari $20 \mathrm{DMU}$ (decision making units) dimana dibagi menjadi 5 kelompok komoditas pangan. Observasi dan wawancara bertujuan untuk memperoleh gambaran umum tentang pertanian tanaman pangan para petani yang merupakan mitra yang menjadi objek penelitian. Analisis data penelitian berdasarkan Data Envelopment Analysis (DEA). Hasil penelitian menunjukkan bahwa dalam aspek efisiensi dana yang memiliki nilai efisiensi teknis mencapai 100\% hanya dalam 2 DMU, yaitu DMU 19 dan DMU 20, yang merupakan klaster S (komoditas singkong). Dalam aspek efisiensi kreativitas, dapat dilihat bahwa hanya di DMU 19 dan DMU 20 (komoditas S atau singkong) yang efisien. Tingkat efisiensi relatif dalam efisiensi bantuan hanya ada 1 DMU yang efisien, yaitu DMU 19 di cluster S (komoditas singkong). Tingkat efisiensi dalam aspek teknologi tepat guna (efisiensi teknis), hanya dicapai oleh 1 DMU, yaitu DMU 19 pada klaster S (Singkong). Ini juga menunjukkan bahwa sebanyak 19 DMU ditandai ketidakefisienan dari perolehan nilai efisiensi $<100 \%$.

Kata kunci:

Efisiensi, Dana Hibah, Kreativitas, Pendampingan, Teknologi Tepat Guna, Nilai Ekonomi

\section{PENDAHULUAN}

Perekonomian Indonesia tidak terlepas dari peran bidang pertanian melalui pengembangan manajemen agrobisnis. Pada aktivitas usaha tani tanaman pangan saat ini kurang diminati karena potensi hasil yang terbatas dan besarnya resiko yang dihadapi. Salah satu faktor penyebabnya karena usaha pertanian yang dikelola secara tradisional lebih menekankan pada aspek teknis budidaya tanaman, terutama tanaman pangan namun aspek bisnis kurang diperhatikan sehingga marginal cost bisa lebih rendah dari pada marginal revenue. Untuk itu usaha tani perlu memiliki tata kelola usaha yang efisien dan berorientasi pasar (market oriented) sehingga memberikan dampak positif pada nilai tambah ekonomi bagi petani. Hal lain yang menjadi pijakan adalah perlunya mewujudkan daya saing yang berbasis pada mind set berbasis orientasi dan inovasi (Alwi:2018). Adopsi inovasi diantaranya dalam berupa inovasi teknologi seperti media informasi, luas

lahan, komunikasi kelompok tani petani, pendidikan, dan pendampingan.

Sektor pertanian memiliki fungsi strategis dalam menjaga ketahanan pangan nasional dan sekaligus menjadi prioritas pembangunan. Namun demikian sektor pertanian, khususnya tanaman pangan memiliki Rasio Output/Input (ROI) yang rendah dibandingkan dengan usaha pada sektor lain. Rendahnya rasio output/input ini juga dialami oleh mitra tani, karena penghasilan pokok yang berasal dari usaha tani bertahun-tahun tidak berkembang, banyak anggota mitra yang beralih profesi ke sektor lain, terutama kaum muda. Kecenderungan ini juga dialami oleh sebagian besar usaha tani di negeri ini yang pada akhirnya menghambat program pencapaian ketahanan pangan. Salah satu cara meningkatkan ROI dalam usaha tani adalah melakukan efesiensi secara terpadu mulai dari hulu ke hilir. Efesiensi dari hulu misalnya pada saat pengelolaan bibit dan pupuk.

Usaha budidaya tanaman pangan sering terhambat oleh faktor-faktor alam dan sistem perdagangan komoditas terkait dengan hasil bumi. Agribisnis tanaman pangan bukan hanya meliputi produk hulu saja seperti budidaya, tetapi meliputi juga perdagangan dan industri pengolahan hasil bumi tanaman pangan. Dengan kata lain agribisnis pangan meliputi semua usaha yang berkaitan dengan produksi, 
perdagangan, dan industri pengolahan produk pertanian tanaman pangan. Usaha budidaya tanaman pangan merupakan usaha yang yang secara umum berfungsi sebagai jaring pengaman pembangunan. Di Indonesia masih memberikan nilai tambah yang rendah tetapi bagi pelaku usaha terkait dan memiliki tingkat resiko tinggi. Hal ini disebabkan beberapa faktor antara lain faktor cuaca, sistem perdagangan komoditas pertanian tanaman pangan dan harga yang tidak stabil, mahalnya input, rendahnya produktivitas tenaga kerja, penerapan teknologi tepat guna yang belum efesien dan pengelolaan yang kurang efektif, terutama pada komoditas beras dan kedelai.

Guna meningkatkan nilai tambah ekonomi pada usaha tani tanaman pangan terutama bagi petani tradisional, perlu diadakan pembenahan dari sisi pendanaan dan penerapan teknologi tepat guna dan metode penggunaan input secara terpadu. Penelitian Prayitno (2007) menemukan bahwa bantuan hibah berpengaruh terhadap peningkatan pendapatan anggota kelompok mitra tani, bahkan pada pengolahan lahan kering.

Penelitian oleh Mawardi (2019) menemukan bahwa salah satu cara meningkatkan nilai tambah komoditas adalah melalui penerapan teknologi tepat guna. Peningkatan nilai tambah komoditas sebagai upaya peningkatan produktivitas petani mitra. Adapun pembenahan dari sisi metode meliputi adaptasi dan kreasi cara kerja yang lebih variatif, hal ini terkait dengan upaya-upaya menciptakan cara kerja yang lebih efesien. Pembenahan dari sisi techno-culture perlu dilakukan secara menyeluruh bukan hanya dari sisi budi daya saja tetapi meliputi pengolahan hasil, pengemasan dan penyimpanan agar standar kualitas tetap terjaga.
Pendampingan kepada petani diantaranya dilakukan melalui tenaga penyuluh yang berperan positif dalam peningkatan pemberdayaan petani, akses informasi, kerjasama dan inovasi (Haryanto:2017). Penyuluh dapat berperan dalam mediator petani dan hasil penelitian serta sosialisasi lebih lanjut dari pengembangan inovasi dan prediksi besaran dana yang dibutuhkan dalam implementasinya (Putri:2018). Pada aspek lain, upaya melalui Kelompok Usaha Bersama (KUBE) dapat dijadikan wahana dalam pemberdayaan masyarakat yang berujung pada upaya pengentasan kemiskinan (Wulan:2019).

Dengan pembenahan dari aspek-aspek tersebut di atas, dalam jangka waktu pendek akan mendorong kreativitas dan penggunaan hasil inovasi serta penerapan teknologi tepat guna di bidang agribisnis, mulai dari hulu sampai hilir. Sedangkan dalam jangka menengah akan mengarah pada industrialisasi bidang usaha tani tanaman pangan. Adapun efek jangka panjang yang diharapkan adalah meningkatnya daya saing produk tanaman pangan sehingga meningkatkan kesejahteraan para petani, terutama petani kecil yang selama ini termarjinalkan, seperti halnya para petani yang tergabung dalam Kelompok Usaha Bersama (KUBE) di Sukamakmur dan Saung Cipamingkis di desa Sukamulya, Kecamatan Sukamakmur, Kabupaten Bogor.

Uraian di atas mendorong penelitian ini terfokus pada efisiensi dana hibah, kreativitas, pendampingan dan implementasi teknologi tepat guna pada nilai ekonomi hasil usaha mitra yang terdiri dari 2 kelompok mitra tani yaitu: Kelompok Tani Saung Cipamingkis dan Kelompok Usaha Bersama Sukamakmur, di desa Sukamulya, kecamatan Sukamakmur, kabupaten Bogor. 


\section{TUJUAN PENELITIAN}

Tujuan yang hendak dicapai dalam penelitian ini adalah untuk mengetahui efisiensi dari dana hibah, kreativitas, pendampingan, dan implementasi teknologi tepat guna pada nilai ekonomi usaha mitra, sehingga dapat disusun model yang sesuai mengenai usaha-usaha untuk meningkatkan nilai ekonomi usaha tani tanaman pangan sekaligus mempermudah upaya-upaya yang dapat dilakukan untuk memberikan nilai tambah pada usaha tani.

\section{TELAAH LITERATUR \\ Konsep Efisiensi}

Efisiensi merupakan selisih antara nilai input atau sumber daya dengan nilai output yang dapat berupa produk fisik maupun non fisik. Efisiensi dapat dinyatakan dalam prosentase untuk mempermudah perhitungan. Secara matematika dapat dinyatakan (V1-V0) : V0 x100\% (Sunarso: 2011). Efisiensi operasional dari setiap kegiatan bisnis berpengaruh dalam pemanfaatan potensi sumber daya yang dimiliki. Efisiensi dapat tercipta melalui kombinasi kreativitas dan inovasi dalam pengelolaan faktor produksi. Soekartawi (2003) membedakan 3 jenis efisiensi yaitu: efisiensi ekonomis, efisiensi teknis dan efisiensi alokatif (harga). Efisiensi teknis mencakup mengenai hubungan antara penggunaan set kombinasi input dan output. Efisiensi teknis mensyaratkan adanya proses produksi yang dapat memanfaatkan input yang lebih sedikit demi menghasilkan output dalam jumlah yang sama.

Ukuran relatif efisiensi dapat dihitung dengan membandingkan output dengan input dengan pendekatan frontier. Pendekatan frontier dibagi menjadi dua yaitu parametrik dan non parametrik. Dalam metode non parametrik salah satu pendekatan yang dapat digunakan adalah Envelopment Analisis (DEA) selain Free Disposal Hull (FDH). DEA digunakan dengan cara mengidentifikasi unit-unit yang akan dievaluasi, berupa input-input yang digunakan dan output yang dihasilkan oleh unit tersebut. Titik efisien berada pada garis batas kumpulan data yang telah dihitung nilai efisiensinya. Unit yang berada diluar garis batas tidak termasuk memenuhi persyaratan efisiensi.

\section{Pentingnya Pendanaan}

Pendanaan merupakan kegiatan mendapatkan dana untuk operasional usaha. Dengan adanya dana yang cukup maka pengadaan barang modal, bahan baku, dan biaya operasional dapat dilakukan secara optimal. Hibah ke masyarakat dimaksudkan untuk meningkatkan aktivitas usaha mitra guna meningkatkan efisiensi dan kreativitas pelaku usaha tani. Kreativitas merupakan modal utama dalam setiap usaha, termasuk usaha tani. Hal ini akan menimbulkan daya cipta. Dengan kata lain kreativitas akan meningkatkan kemampuan untuk menciptakan suatu yang bermutu. Kreativitas merupakan sumber daya ekonomi yang sangat bernilai dengan menghadirkan ide dan cara baru yang lebih baik dalam rangka meningkatkat produktivitas dan standar hidup.

Kreativitas terkait juga dengan kemampuan berimajinasi dan inisiatif dalam menghasilkan solusi yang baru, barang atau jasa baru, perbaikan cara kerja, atau pun metode baru yang memungkinkan memberikan kontribusi yang lebih baik. Bahkan penggunaan bahan baru yang lebih ekonomis dan penggunaan alat-alat kerja juga merupakan kreativitas. 


\section{Kreativitas dalam Usaha Tani}

Kreativitas muncul melalui proses panjang mulai dari pencarian ide atau gagasan sampai pada dihasilkannya sesuatu yang baru yang lebih produktif, efektif dan efisien secara sistematis dan skematis. Proses lahirnya kreativitas ini perlu distimulir melalui hal-hal yang inspiratif. Kehadiran tenaga pendamping yang mendampingi para petani merupakan stimulus dalam rangka membangkitkan inspirasi, sebagai tahap awal timbulnya kreativitas. Sektor pertanian mengalami defisit kreativitas dan bahkan berjalan mundur, kehadiran para ahli terutama para akademisi dan teknokrat di tengah petani akan mendorong timbulnya energi positif menuju arah kemajuan yang pada akhirnya akan mendorong daya saing bidang agribisnis, khususnya usaha tani tanaman pangan.

Kreativitas di kalangan petani adalah hal belum membudaya, boleh dikatakan sejak jaman orang tua mereka sampai dengan saat ini cara-cara kerja tani mereka relatif tidak berubah, bukannya taraf hidup yang lebih baik yang diperoleh, tetapi justru kian termarjinalkan di tengah meningkatnya kemakmuran di sektor industri dan jasa. Hal ini akan mendorong alih profesi dari sektor pertanian ke sektor lain.

Guna mempercepat timbulnya proses kreatif di kalangan petani, sebagai langkah awal timbulnya kreativitas, diperlukan stimulus. Namun stimulusnya bukan berupa materi tetapi berupa spirit. Secara lebih jelas proses timbulnya kreativitas dapat digambarkan secara hirarkis mulai dari stimulir, motivasi, inspirasi, ide dan gagasan, selanjutnya akan terjadi proses kreatif yang melahirkan nilai tambah. Dengan adanya nilai tambah daya saing dan kesejahteraan petani akan meningkat.

\section{Pendampingan (Assistance)}

Pendampingan sangat diperlukan oleh para petani. Menghadirkan para ahli di tengah para petani memang bukan perkara mudah, karena sedikitnya program yang tersedia. Bagi para akademisi apapun latar belakang keilmuannya, hal ini dapat dilakukan melalui kegiatan pengabdian pada masyarakat sebagai wujud pelaksanaan tridharma perguruan tinggi. Memang kegiatan pengabdian pada masyarakat tidak harus dalam bentuk kunjungan langsung kepada para petani, bisa di tempat lain yang lebih bersih dan nyaman. Hal ini dapat dilakukan dengan mengimplementasikan teknologi tepat guna.

Dengan melakukan interaksi dengan para ahli secara edukatif, para petani sebagai pelaku usaha yang secara relatif kurang dalam pendidikan dan pengetahuan dapat melek teknologi. Walaupun kaum terdidik dan berpengetahuan tidak menjadi petani langsung, tetapi konsep-konsep yang bersifat umum seperti efisiensi dan nilai tambah dapat membantu usaha tani tanaman pangan. Boleh saja kaum terdidik tidak tertarik untuk berprofesi sebagai petani karena memang tidak menjanjikan, namun ini tidak perlu dipermasalahkan, karena memilih profesi adalah hak setiap orang yang terkait dengan tuntutan hidup, tetapi tidak seharusnya meninggalkan sektor pertanian, setidaknya memberikan kontribusi berupa cara-cara kreatif untuk meningkatkan nilai ekonomi dari usaha tani. Dengan adanya interaksi antara petani dengan orang-orang yang memiliki kemampuan dari berbagai latar belakang keahlian akan meningkatkan kreativitas. Hal ini dapat dilakukan melalui upaya pendampingan dalam usaha tani secara berkesinambungan, terutama dengan para pakar dan akademisi. 


\section{Implementasi Teknologi Tepat Guna}

Pada bidang agribisnis usaha-usaha menemukan produk hulu baru sulit dilakukan, karena produk hulu agribisnis merupakan hasil panen yang langsung diambil dari petani yang masih memiliki nilai tambah rendah. Namun demikian, walaupun produknya sama tetapi dengan adanya cara kerja, penggunaan bahan, dan alat yang lebih baik akan meningkatkan nilai tambah karena adanya kenaikan produk marginal dan kualitas yang lebih baik. Berbeda dengan produk hulu, pada produk hilir penemuan produk baru yang memiliki nilai tambah lebih tinggi sangat dimungkinkan melalui industrialisasi agribinis. Teknologi tepat guna yang diterapkan sebagai kreasi inovatif dapat meningkatkan produktivitas dan pendapatan nmasyarakat (Purwanti:2019).

\section{Nilai Ekonomi}

Setiap akivitas usaha mulai dari pencarian bahan baku, desain produk, pembangunan fasilitas produksi, produksi, distribusi, promosi, perdagangan dan lainlain sepanjang biaya yang dikeluarkan lebih kecil dari pendapatan menghasilkan nilai tambah. Tiap tahapan aktivitas usaha mulai dari pembelian bahan baku, konversi dari bahan baku menjadi produk, promosi, pergudangan, transportasi, dan pelayanan konsumen mengeluarkan biaya, dimana total biaya tersebut menentukan daya saing produk yang dihasilkan. Semakin kecil total biaya yang dikeluarkan semakin unggul dalam bersaing. Pada Bidang agribisnis, terutama pada usaha tani tanaman pangan jika dihitung biaya keseluruhan termasuk biaya tenaga kerja yang dilakukan sendiri oleh petani secara ekonomi belum menutup biaya-biaya, sehingga nilai tambah yang diterima petani negatif.

Dalam siklus ekonomi secara makro, biaya yang dikeluarkan oleh pelaku usaha tani merupakan pendapatan atau nilai yang diperoleh oleh pihak pemasok. Biaya pupuk, obat-obatan dan bibit yang digunakan untuk merupakan pendapatan bagi pemasok bahan baku tersebut. Biaya yang dibayarkan kepada para buruh tani merupakan pendapatan bagi buruh tersebut. Biaya yang dikeluarkan untuk membayar sewa lahan merupakan pendapatan bagi pemilik lahan tersebut. Secara kumulatif nilai yang diciptakan mulai dari awal sampai tahap berikutnya akan menambah likuiditas ekonomi. Hal inilah yang menciptakan rantai nilai. Rantai nilai kumulatif ini secara total menentukan tingkat pendapatan perkapita yang sebagai indikator kemakmuran masyarakat. Usaha tani tanaman pangan secara kumulatif memberikan nilai tambah bagi ketahanan sektor usaha lain, namun bagi petani itu sendiri justru kadangkadang memberi nilai negatif, walaupun secara makro memberikan nilai tambah positif.

\section{METODE PENELITIAN Metode Pengumpulan Data}

Metode pengumpulan data yang digunakan adalah observasi lapangan dan wawancara dengan responden yang terdiri dari petani mitra. Observasi lapangan dimaksudkan untuk mendapatkan data sesuai dengan kondisi sebenarnya di lapangan. Wawancara bertujuan untuk memperoleh gambaran umum tentang usaha tani tanaman pangan para petani yang mitra yang menjadi objek penelitian.

Analisis data penelitian berbasiskan data envelopment analysis (DEA). Analisis DEA merupakan pendekatan untuk mengetahui efisiensi relatif secara teknis melalui pendekatan frontier (batasan) berupa aplikasi pendekatan non parametrik melalui teknik linear 
programming, dengan berpedoman pada asumsi bahwa tidak ada random error.

Melalui penggunaan metode DEA peneliti dapat membandingkan antara data input dengan data output dari unit-unit yang membuat keputusan (decision making units atau DMU) yang terdiri dari 20 DMU yang terbagi pada 5 kelompok atau klaster komoditas pangan dari 2 kelompok mitra yaitu kelompok tani Saung Cipamingkis dan kelompok usaha bersama Sukamakmur, di desa Sukamulya, kecamatan Sukamakmur kabupaten Bogor.

\section{Objek Penelitian}

Objek penelitian adalah para petani yang tergabung dalam 2 kelompok tani mitra yaitu: Kelompok Tani Saung Cipamingkis dan Kelompok Usaha Bersama Sukamakmur, di desa Sukamulya, kecamatan Sukamakmur, kabupaten Bogor. Berdasarkan informasi tersebut diperoleh gambaran mengenai cara kerja, biaya dan hasil yang diperoleh dari hasil kegiatan mitra. Sebagian dari anggota mitra telah bertani selama lebih dari 30 tahun. Masing-masing anggota mitra dianggap sebagai decision making unit (DMU) yang independen. Observasi dilakukan terhadap hasil rata-rata di masing-masing mitra hasil dilihat dari dana hibah, kreativitas, pendampingan dan teknologi tepat guna. Hasil perhitungan nilai tambah pada objek terbaik di masing-masing blok kemudian di bandingkan dengan nilai tambah yang diperoleh pada pilot project dan dikelompokkan dalam 5 kluster. Pencatatan dilakukan dalam musim hujan antara Agustus 2018 s/d Desember 2018.

\section{Variabel Penelitian}

Dalam penelitian ini digunakan 5 variabel yang terdiri dari 4 variabel input dan 1 variabel output. Variabel input terdiri dari dana hibah, kreativitas, pendampingan dan implementasi teknologi tepat guna, sedangkan variabel output adalah nilai ekonomi hasil usaha mitra.

Untuk mengukur skor hasil penelitian per klaster, masing-masing variabel diberi skala bobot 1-5, sedangkan skor total dihitung dengan menjumlahkan perolehan skor semua variabel untuk masing-masing klaster. Untuk mempermudah perhitungan masing-masing variabel diindikasikan sebagai berikut.

Tabel 1.

Variabel dan Indikator

\begin{tabular}{|c|c|c|}
\hline No & Variabei & Intikator \\
\hline 1 & $\begin{array}{l}\text { Dana Hibah } \\
\text { (genat fund) }\end{array}$ & $\begin{array}{l}\text { a) Bahan } \\
\text { b) Alat } \\
\text { c) Tenaga kerja }\end{array}$ \\
\hline 2 & $\begin{array}{l}\text { Rreativitas } \\
\text { (creativity) }\end{array}$ & $\begin{array}{l}\text { a) Ide } \\
\text { b) Proses } \\
\text { c) Cara Kerja }\end{array}$ \\
\hline 3 & $\begin{array}{l}\text { Pesdampingan } \\
\text { (Asststence) }\end{array}$ & $\begin{array}{l}\text { a) Iatensitas Pelatihan } \\
\text { b) Pendampingan } \\
\text { Lapangan } \\
\text { c) Kenaltasi }\end{array}$ \\
\hline 4 & $\begin{array}{l}\text { Implementasi Teiknologi Tepat Guna } \\
\text { (Timplementatian of Appropviate } \\
\text { Teclinailog) }\end{array}$ & $\begin{array}{l}\text { a) Kelengkapan alat } \\
\text { b) Ketersediasn bahan } \\
\text { c) Kecakapan Operator }\end{array}$ \\
\hline 5 & Nilai Elkonomi Haril Usaha Mitra. & $\begin{array}{l}\text { a) Produktivitas } \\
\text { b) Nilai tambab komoditas } \\
\text { c) Pendajatan }\end{array}$ \\
\hline
\end{tabular}

\section{Analisis Data}

Teknik analisis data menggunakan pendekatan DEA dapat mengindikasikan efisiensi mitra dengan menggunakan rasio perhitungan input dan output dari setiap anggota mitra. Efisiensi usaha tani mitra diukur dengan formulasi sebagai berikut: Jumlah output yang diamati dibagi dengan Jumlah input. Bobot output i yang dihasilkan per DMU vj = Bobot input $j$ yang digunakan per DMU. Rasio efisiensi (hs) akan dimaksimalkan dengan kendala sebagai $\mathrm{Vj} \leq 1$; dimana $\mathrm{Ui}$ dan $\mathrm{Vj} \geq 0$ Persamaan ini menjelaskan bahwa adanya rasio relatif dari DMU bukan efisiensi absolut. Semakin mendekati 1 semakin baik, dengan tidak lebih dari 1 dan memiliki nilai positif. Mitra akan dikatakan efisien apabila memiliki nilai efisiensi mendekati 1 atau 100 persen. Sebaliknya 
mitra akan dikatakan tidak efisien apabila memiliki nilai mendekati nol (0). Dengan DEA, dapat menentukan tingkat efisiensi usaha mitra. Dalam analisis ini dilakukan pembobotan variabel secara pro rata sehingga hasilnya masing-masing dan menjamin bahwa pembobot yang dipilih akan menghasilkan ukuran kinerja terbaik.

\section{PEMBAHASAN}

\section{Gambaran Objek Penelitian}

Dari hasil observasi awal kami memilih dua kelompok mitra sebagai obyek penelitian yaitu Kelompok Usaha Bersama (KUBE) Sukamakmur dan Kelompok Usaha Tani (KUT) Saung Cipamingkis. Kedua mitra berdomisili di Desa Sukamulya Kecamatan Sukamakmur, Kabupaten Bogor Jawa Barat. Objek penelitian tersebut terletak pada daerah rawan secara sosial ekonomi. Mitra usaha tani adalah kelompok masyarakat tani yang umumnya tidak muda lagi, namun memiliki komitmen untuk mengelola usaha tani, sehingga untuk sementara anggota mitra masih terdiri dari orangorang tua yang seharusnya sudah pensiun. Anggota merupakan para petani tradisional yang telah menekuni usaha tani secara turun-temurun, namun dari waktu ke waktu tidak menunjukkan perbaikan yang signifikan.

Kedua petani mitra tersebut berusaha pada sektor pertanian tradisional. Kedua mitra juga memiliki permasalahan yang sama yaitu terkendala prasarana, sarana dan fasilitas usaha tani. Salah satu kendala yang dihadapi mitra adalah minimnya peralatan, lokasi yang terpencil, dan kondisi lahan yang berat. Sebenarnya ketersediaan lahan pertanian cukup luas, namun sebagian berupa tanah daratan yang tandus dengan struktur tanah berat terdiri dari lempung putih dan batubatuan. Kondisi lahan tandus tersebut menyulitkan petani dalam pengolahannya. Kalaupun dikelola hasilnya tidak seimbang dengan biayanya yang berujung pada capaian hasil yang tidak memberikan nilai ekonomi yang tinggi.

Hal inilah yang menyebabkan banyak lahan kering yang terbengkalai dan tidak dapat terkelola dengan baik, disamping itu musim kemarau mengakibatkan aktivitas bercocok tanam di lahan kering mengalami gagal panen. Sebagai upaya mengatasi masalah tersebut dilakukan pendekatan melalui alokasi dana hibah, kreativitas, pendampingan dan implementasi teknologi tepat guna pada petani mitra dalam meningkatkan nilai ekonomi hasil usaha mitra.

\section{Produktivitas Sektoral}

Salah satu cara meningkatkan efisiensi sektor pertanian adalah dengan cara menghemat penggunaan penggunaan benih dan pupuk. Penggunaan kemasan bibit dan pupuk terpadu sistem anguler dalam bercocok tanam tanaman pangan tidak hanya dapat menghemat benih dan pupuk, namun juga akan menghemat waktu dan tenaga yang pada akhirnya dapat menciptakan efesiensi biaya dan waktu penanaman.

Pengemasan benih dan pupuk secara anguler juga berperan dalam menjaga mutu fisiologik benih dan dapat mengembangan industri benih tanaman yang memegang peranan yang sangat penting. Kondisi fisik seperti kebersihan, kesegaran butiran serta keutuhan keadaan kulit benih penting karena benih dalam kemasan akan menjadi lebih terlindungi. Dampak positif dari pengelolaan benih dan pupuk akan meningkatkan efesiensi.

Efesiensi dari hulu pada sektor pertanian dilakukan mulai dari tahap pra tanam hingga tahap pasca panen harus dilakukan sehingga rasio output/input meningkat. Selain itu perubahan atau 
transformasi struktural sektor pertanian ini, dapat mengakibatkan usaha tani tradisional yang kurang efesien berubah menjadi usaha tani komersial yang berorientasi pada prinsip-prinsip efisiensi dan nilai tambah ekonomi, karena perkembangan sektor pertanian bukan saja terjadi di hulu (saat proses penanaman) tetapi juga di hilir pengolahan hasil panen, termasuk untuk benih. Dengan demikian efesiensi dilakukan mulai dari pengelohan pra tanam, proses penanaman, pemeliharaan tanaman, panen, pasca panen, distribusi, komersialisasi dan industrialisasi sektor pertanian.

\section{Analisis Data Hasil Penelitian}

Data hasil pengamatan dianalisis dengan pendekatan DEA yang tujuannya untuk mengkategorikan tingkat efisensi berdasarkan klaster. Ada empat klaster yang diamati yang semuanya berbasis komoditas pangan yang terdiri dari 4 klaster mitra yaitu mitra yang memilih komoditas jagung (klaster J); komoditas kedelai (klaster K); komoditas Padi (klaster P) dan komoditas singkong (klaster S). Aspek penilaian efisiensi dari keempat klaster tersebut dianalisis lebih lanjut pada aspek efisiensi dana hibah (fund efficiency), efisiensi kreativitas (creativity efficiency), efisiensi pendampingan (assistance efficiency) dan efisiensi teknologi tepat guna (technical efficiency).

Berdasarkan analisis DEA atas kinerja para mitra yang terdiri dari 20 unit DMU, yang dikelompokkan ke dalam empat klaster yaitu klaster J (Jagung), K (Kedelai), P (Padi), dan S (Singkong) diperoleh tabel efisiensi DMU sebagai berikut:
Tabel 2.

Efisiensi Per Klaster

\begin{tabular}{|l|l|l|l|l|l|l|}
\hline \multicolumn{7}{|c|}{ EFFICIENCY SUMMARY: } \\
\hline DMU & CLS & FE & CE & AE & TE & Mean \\
\hline 1 & J & 0.87 & 0.77 & 0.87 & 0.77 & 0.82 \\
\hline 2 & J & 0.87 & 0.87 & 0.87 & 0.87 & 0.87 \\
\hline 3 & J & 0.87 & 0.58 & 0.87 & 0.87 & 0.80 \\
\hline 4 & J & 0.62 & 0.87 & 0.87 & 0.87 & 0.81 \\
\hline 5 & K & 0.81 & 0.87 & 0.81 & 0.81 & 0.83 \\
\hline 6 & K & 0.58 & 0.87 & 0.87 & 0.87 & 0.80 \\
\hline 7 & K & 0.87 & 0.87 & 0.87 & 0.87 & 0.87 \\
\hline 8 & K & 0.87 & 0.87 & 0.87 & 0.87 & 0.87 \\
\hline 9 & K & 0.87 & 0.54 & 0.87 & 0.87 & 0.79 \\
\hline 10 & K & 0.87 & 0.87 & 0.87 & 0.87 & 0.87 \\
\hline 11 & K & 0.87 & 0.87 & 0.54 & 0.87 & 0.79 \\
\hline 12 & P & 0.87 & 0.87 & 0.87 & 0.87 & 0.87 \\
\hline 13 & P & 0.81 & 0.87 & 0.81 & 0.81 & 0.83 \\
\hline 14 & P & 0.81 & 0.81 & 0.87 & 0.81 & 0.83 \\
\hline 15 & P & 0.81 & 0.81 & 0.87 & 0.81 & 0.83 \\
\hline 16 & P & 0.81 & 0.81 & 0.93 & 0.81 & 0.84 \\
\hline 17 & P & 0.87 & 0.87 & 0.87 & 0.87 & 0.87 \\
\hline 18 & P & 0.87 & 0.87 & 0.65 & 0.87 & 0.82 \\
\hline 17 & P & 0.87 & 0.87 & 0.87 & 0.87 & 0.87 \\
\hline 18 & P & 0.86 & 0.87 & 0.72 & 0.90 & 0.84 \\
\hline 19 & S & 1.00 & 1.00 & 1.00 & 1.00 & 1.00 \\
\hline 20 & S & 1.00 & 1.00 & 0.87 & 0.87 & 0.94 \\
\hline & Mean & 0.84 & 0.84 & 0.88 & 0.86 & 0.85 \\
\hline Note: & & & & & & \\
& FE $=$ Fund Efficiency & & & \\
\hline & AE $=$ Assistance Efficiency & & & \\
\hline
\end{tabular}

Sumber: hasil pengolahan data DEA

Berdasarkan hasil perhitungan efisiensi pada 20 DMU yang terbagi pada 4 klaster komoditi dapat diketahui bahwa pada aspek efisiensi dana hibah (fund efficiency) yang memiliki nilai efisien teknis mencapai $100 \%$ hanya pada 2 DMU saja yaitu DMU 19 dan DMU 20 yang merupakan klaster S (komoditas Singkong).

Hasil perhitungan efisiensi pada 20 DMU pada aspek efisiensi kreativitas (creativity efficiency) dapat diketahui bahwa hanya pada DMU 19 dan DMU 20 (klaster S atau komoditas Singkong) yang efisien. 
Tingkat efisiensi relatif pada aspek pendampingan (assistance efficiency) hanya terdapat 1 DMU saja yang efisien yaitu DMU 19 pada klaster S (komoditas Singkong).

Tingkat efisiensi pada aspek teknologi tepat guna (technical efficiency), hanya diraih oleh 1 DMU saja yaitu DMU 19 pada klaster S (Singkong). Hal ini menunjukkan pula bahwa sebanyak 19 DMU yang inefisien yang ditandai dari perolehan nilai efisiensi $<100 \%$.

Satu hal yang menarik adalah pada DMU 19 yang merupakan klaster komoditi Singkong merupakan satu-satunya DMU dan kluster yang mampu meraih tingkat efisiensi pada keseluruhan aspek, baik pada aspek efisiensi dana hibah, efisiensi kreativitas, pendampingan dan efisiensi teknologi tepat guna. Hal tersebut dapat diketahui dari nilai efisiensi sebesar 1 atau $100 \%$ dari masing-masing aspek yang dinilai, dan total nilai rata-rata (mean) dari keempat aspek efisiensi yang diteliti.

DMU berikutnya, yang memiliki nilai rata-rata (mean) tinggi adalah pada DMU 20 dengan mean sebesar 0,94 dimana kontribusi nilai efisien diperoleh dari efisiensi dana hibah dan efisiensi kreatifitas (masing-masing bernilai 1) dan aspek efisiensi pendampingan serta aspek efisiensi teknologi tepat guna masingmasing sebesar 0,87.

Yang menarik terlihat pada perbandingan antara nilai rata-rata (mean) capaian efisiensi diantara keempat variabel yaitu pada efisiensi dana hibah, efisiensi kreativitas, efisiensi pendampingan dan efisiensi teknologi tepat guna. Berdasarkan nilai rata-rata efiensi yang tertinggi diperoleh pada aspek efisiensi teknologi tepat guna (senilai 0,86), selanjutnya efisiensi pada aspek pendampingan $(0,85)$, sedangkan pada aspek kreativitas dan dana hibah masing-masing senilai 0,84 atau $84 \%$.
Adapun perbandingan antara nilai rata-rata (mean) efisiensi diantara $20 \mathrm{DMU}$ yang diteliti dapat diketahui bahwa satusatunya DMU yang efisien pada keseluruhan variabel input (aspek dana hibah, aspek kreativitas, aspek pendampingan dan aspek teknologi tepat guna) adalah DMU 19 yang berada pada klaster komoditi Singkong. Nilai rata-rata selanjutnya yang relatif tinggi adalah pada DMU 20 dengan nilai mean sebesar 0,94. Nilai ini diperoleh dari kontribusi masingmasing pada aspek dana hibah dan kreativitas mencapai nilai efisien (pada nilai 1 atau $100 \%$ ) dan masing-masing pada aspek pendampingan dan aspek teknologi sebesar 0,87 atau $87 \%$.

Dikaitkan dengan efisiensi dari variabel input dana hibah, kreativitas, pendampingan dan implementasi teknologi tepat guna pada variabel output nilai ekonomi mitra dengan indikasi peningkatan produktivitas kelompok mitra tani, nilai tambah komoditas dan peningkatan pendapatan petani mitra lebih didominasi dari kluster tanaman Singkong (Kluster S). Hal tersebut secara spesifik dapat diketahui dari hasil penelitian bahwa yang memberikan tingkat efisiensi dalam peningkatan ekonomi adalah pada alokasi dana hibah dengan nilai efisien teknis mencapai 100\% hanya pada DMU 19 dan DMU 20 berbasi klaster S (komoditas Singkong). Pada aspek efisiensi kreativitas (creativity efficiency) juga hanya pada DMU 19 dan DMU 20 (klaster S atau komoditas Singkong) yang efisien. Adapun tingkat efisiensi relatif pada aspek pendampingan (assistance efficiency) hanya terdapat 1 DMU saja yang efisien yaitu DMU 19 pada klaster S (komoditas Singkong). Sedangkan tingkat efisiensi pada aspek teknologi tepat guna (technical efficiency), hanya diraih DMU 19 pada klaster S (Singkong). 


\section{KESIMPULAN}

Berdasarkan uraian di atas maka dapat disimpulkan hal-hal sebagai berikut:

1. Pada aspek efisiensi dana hibah (fund efficiency) yang memiliki nilai efisien teknis mencapai $100 \%$ hanya pada 2 DMU saja yaitu DMU 19 dan DMU 20 yang merupakan klaster $S$ (komoditas Singkong).

2. Pada aspek efisiensi kreativitas (creativity efficiency) dapat diketahui bahwa hanya pada DMU 19 dan DMU 20 merupakan klaster $S$ atau komoditas Singkong yang mencapai efisien $100 \%$..

3. Tingkat efisiensi relatif pada aspek pendampingan (assistance efficiency) hanya terdapat 1 DMU saja yang efisien yaitu DMU 19 pada klaster S (komoditas Singkong).

4. Tingkat efisiensi pada aspek teknologi tepat guna (technical efficiency), hanya diraih oleh 1 DMU saja yaitu DMU 19 pada klaster $S$ (Singkong). Hal ini menunjukkan pula bahwa sebanyak 19 DMU yang inefisien yang ditandai dari perolehan nilai efisiensi $<100 \%$.

5. Kluster tanaman Singkong (Klaster S) memberikan kontribusi efisiensi dalam capaian nilai ekonomi mitra tani dalam peningkatan produktivitas, nilai tambah komoditas dan pendapatan petani.

\section{SARAN}

1. Guna meningkatkan efisiensi usaha tani perlu ada kerja sama antar stake holder, khususnya pemerintah sebagai pembuat kebijakan di bidang agribisnis

2. Disiplin ilmu manajemen, baik pada tatanan produksi, dan manajemen pemasaran perlu mendapatkan atensi lebih guna pengembangannya di kalangan petani guna peningkatan produktivitas dan nilai ekonomi.

3. Inovasi yang dihasilkan dari penelitian serta pengembangan teknologi tepat guna terutama dari hasil risest berbasis tenaga akademisi dapat dilakukan diseminasi lebih lanjut bagi petani. Peneliti dari kampus dapat berperan serta sebagai pendamping yang diharapkan sebagai motor penggerak motivasi para petani melalui pengelolaan dan manajemen tata kelola pertanian.

\section{DAFTAR PUSTAKA}

Alwi, Taufik dan Handayani, Esti. 2018. Keunggulan Bersaing UKM yang Dipengaruhi oleh Orientasi Pasar dan Inovasi Produk, Jurnal Pengembangan Wiraswasta, Vol. 20 No. 03

Haryanto, Yoyon. dkk. 2017. Efektivitas Peran Penyuluh Swadaya dalam Pemberdayaan Petani di Provinsi Jawa Barat, Jurnal Pengkajian dan Pengembangan Teknologi Pertanian, Vol. 20, No. 2: 141-154

Mawardi, Indra. dkk. 2019. Penerapan Teknologi Tepat Guna Pascapanen dalam Upaya Peningkatan Produktifitas Petani Kopi di Kabupaten Bener Meriah, Caradde: Jurnal Pengabdian Kepada Masyarakat, Vol. 1. No. 2.

Prayitno, Hendrik. 2007. Analisis Pengaruh Dana Hibah Prestasi terhadap Pendapatan Anggota Kelompok Pengembangan Partisipasi Lahan Kering Terpadu, J-SEP, Vol. 1 No. 2:3647.

Purwanti, Sri. dkk, 2019. Implementasi Teknologi Kreatif Dalam Mewujudkan UMKM Produktif Melalui Program Kemitraan Masyarakat (PKM)

(Kelurahan Kertajaya, Kecamatan Gubeng Kota Surabaya), Jurnal Pengabdian LPPM Untag Surabaya. Vol. 4, No. 1: 49-54. 
Putri, Rizky. dan Safitri, Reza. 2019. Peran Penyuluh Pertanian Terhadap Penerapan Teknologi Tanam Jajar Legowo 2:1 (Kasus Kelompok Tani Gotong Royong 2 di Desa Klaseman, Kabupaten Probolinggo), Jurnal Ekonomi Pertanian dan Agribisnis (JEPA), Vol. 2. No. 3: 167-178.

Soekartawi. 2003. Teori Ekonomi Produksi dengan Pokok Bahasan Analisis Fungsi Produksi. PT. Raja Grafindo Persada, Jakarta.

Sunarso. 2011. Peran Bimbingan Manajemen dalam Meningkatkan
Nilai Tambah Pada Sektor Usaha Informal, Jurnal Pengembangan Wiraswasta, Vol. 13.

Wulan, dkk. 2019. Implementasi Kebijakan Penanggulangan Kemiskinan Melalui Program Pemberdayaan Ekonomi Kelompok Usaha Bersama (KUBE) (Studi Tentang Program Pemberdayaan Ekonomi Kelompok Usaha Bersama (KUBE) di Kelurahan Pakistaji Kecamatan Wonoasih Kota Probolinggo, Jawa Timur), Jurnal Respon Publik, Vol. 13. No. 4: 104-109. 